ISSN 0258-7122

Bangladesh J. Agril. Res. 37(4): 551-558, December 2012

\title{
VARIABILITY IN GRAIN QUALITY TRAITS OF AROMATIC RICE (Oryza sativa' L.)
}

\author{
M. PARIKH ${ }^{1}$, N. K. RASTOGI ${ }^{2}$ AND A. K. SARAWGI ${ }^{3}$
}

\begin{abstract}
The present study involved the evaluation of physio-chemical characters and cooking quality of 36 rice genotypes from Madhya Pradesh and Chhattisgarh. The fine grain genotypes like Rajim-12, Kalimuchh, and Munibhog were found good for moderate kernel length and L:B ratio; Rajabhog, Jhulari, and Baghmuchha for kernel length after cooking and L:B ratio of cooked rice Kalajira and Bikoni for head rice recovery\%; Barang, Bantaphool, Gangabalu, and Bikoni for elongation ratio; Barang, Rajabhog, Gangabalu, Bikoni, and Chirainikhi for elongation index; Sonth, Rajim-12, Jhulari, Gangabalu, Jhilli Safri, and Bikoni for intermediate alkali values. These genotypes may be utilized as donors for improvement of quality traits. In the present study, superior genotypes were Rajm-12 for grain yield, kernel length, L:B ratio and kernel length after cooking; Rajabhog for grain yield, kernel length after cooking, L:B of cooked rice and elongation index; Bikoni for head rice recovery, elongation ratio, elongation index, and intermediate alkali values.
\end{abstract}

Keywords: Aromatic rice, grain quality, variability.

\section{Introduction}

Rice crop is interwoven in the cultural, social and economic lives of millions of Indians and it holds the key for food and nutritional security of the country. India has the largest area and got second rank in rice production among the rice growing countries. However, its share for export in international market is less than five percent due to lacking in grain quality. characteristics. Rice quality includes head rice recovery, kernel size, kernel shape, kernel length after cooking, elongation ratio, elongation index, and aroma. Scented rice has important place to earn more foreign currency due to its pleasant aroma, superfine grain, excellent cooking and eating quality. Hence, it is necessary to impiove grain quality of modern rice varieties to fulfill the demand of the consumers in domestic as well as in international markets. In the present study, attempts have been made to characterize a set of aromatic rice germplasm for various physico-chemical characters and estimate the variabilities available in the collections, which can be utilized as donors in quality improvement for domestic as well as for export purpose.

\footnotetext{
${ }^{1,2 \& 3}$ Department of Genetics and Plant Breeding, College of Agriculture, Indira Gandhi Krishi Vishwavidhalaya, Raipur (Chhattisgarh)-492006
} 


\section{Materials and Method}

The material included 36 native cultivars and landraces some of which were collected from tribal community of Madhya Pradesh and Chhattisgarh region (Table 1). The materials were grown in randomized complete block design in three replications during Kharif 2008. A single seedling of each genotype was transplanted in $2 \mathrm{~m}$ row length adopting $20 \mathrm{~cm}$ distance between rows and $15 \mathrm{~cm}$ between plants. All the recommended agronomic practices were followed to raise a good crop.

A composite sample of five randomly selected plants from each plot was used to record observations on seed yield and quality characters viz., kernel length: breadth ratio (L:B), kernel length after cooking (KLAC), length: breadth ratio of cooked rice, milling \%, head rice recovery \% (HRR \%), elongation ratio, elongation index, alkali spreading value, and 100seed weight.

The seed samples were hulled and milled by Satake huller and miller. Unbroken kernels obtained from milling were used to calculate head rice recovery. Kernel length and breadth were measured by dial micrometer and then ratio of kernel length to kernel breadth (L:B ratio) was computed. Similarly, for kernel length after cooking, ten cooked rice were taken and individual length was measured ratio of length of cooked rice to breadth of cooked rice was also computed. Elongation ratio was computed as length of cooked kernel to length of kernel and kernel elongation index was also computed as length: breadth ratio of cooked rice to length: breadth ratio of milled rice. Alkali spreading value was measured by standard method of Little et al. (1958). Statistical analysis was undertaken for 11 quantitative traits to estimate the genetic parameters. Genotypic and phenotypic coefficients of variability were calculated following a method of Burton (1952). Heritability and genetic advance were estimated as suggested by Johnson et al. (1955).

\section{Results and Discussion}

The aromatic rice genotypes under study showed a wide range of differences for all the characters indicating the existence of high variability among the varieties. Thus, there is an ample scope for selection of seed yield and different quality characters. Enormous variations were also reported in majority of quality characters by Shahidullah et al. (2009). A perusal of GCV revealed that maximum value of variation was recorded for 100-seed weight (26.93\%) followed by seed yield per plant (23.98\%), kernel length: breadth ratio (18.16\%), and length: breadth ratio of cooked rice (14.06\%) (Table 2). These results were in conformation with the findings of Pandey and John Anurag (2010) and Rathi etal. (2010). 
Table 1. Details of rice accessions.

\begin{tabular}{|c|c|c|c|c|c|}
\hline \multirow{2}{*}{ S. No. } & \multirow{2}{*}{ Genotypes } & \multicolumn{4}{|c|}{ Source } \\
\hline & & Acc. No. & Distt. & Block & Village \\
\hline 1 & Bikoni & B:525II & Rajnandgaon & Kawardha & - \\
\hline 2 & Bantaphool & B:10841 & Sidhi & Devsar & Niwap \\
\hline 3 & Bantaphool & B:1090 & Sidhi & Sihabal & Sabin \\
\hline 4 & Bagmuchha & B:1689 & Seoni & Barghat & Dhamakala \\
\hline 5 & Banspatri & B:2357 & Raipur & Mainpur & Idagaon \\
\hline 6 & Barang & B:1166 & Raipur & Deobhog & Kodevan \\
\hline 7 & Badshahbhog & B:323II & Bastar & Gidam & Kasoli \\
\hline 8 & Bhantaphool & B:1087 & Sidhi & Rampurnekin & Sanda \\
\hline 9 & Chhatri & C:808 & Seoni & Barghat & Takhakala \\
\hline 10 & Chinikapoor & C: 340 & Bastar & Bhanupratabpur & Jampara \\
\hline 11 & Chirainikhi & C:751 & Bastar & Lohandikada & Ennur \\
\hline 12 & Dudgi & D:1205 & Raigarh & Gharboda & Pusslada \\
\hline 13 & Dudaga & D:1161I & Bilaspur & Katghora & Chhinpur \\
\hline 14 & Dumarphool & D:822 & Bastar & Kanker & Bewatri \\
\hline 15 & Dumarphool & D:1004 & Bastar & Bastanar & Gotiapal \\
\hline 16 & Ganga Balu & G:751 & Raipur & Saraipali & Bodalawali \\
\hline 17 & Ganga Barud & G:397 & Bastar & Dantewada & Kawalnar \\
\hline 18 & Ganga Prasad & G:433 & Durg & Soj a & Padubhsara \\
\hline 19 & Garrakat & G:1 13111 & Raipur & Tilda & Modhi \\
\hline 20 & Jhiili Safri & $\mathrm{J}: 109 \mathrm{IV}$ & Rajnanadgaon & Dongargaon & - \\
\hline 21 & Jhulari & $\mathrm{J}: 28$ & Jabalpur & Majholi & Kharma \\
\hline 22 & Jira & $\mathrm{J}: 214 \mathrm{IV}$ & Bastar & Gidarn & Ronje \\
\hline 23 & Jiradhan & $\mathrm{J}: 50$ & Jhabua & Bhabra & Bhabra \\
\hline 24 & Kalajira & K:1445 & Raigarh & Bagicha & Gaylunga \\
\hline 25 & Krishnabhog & K:1019 & Durg & Durgikondal & Chaurgaon \\
\hline 26 & Kalimuchh & $\mathrm{K}: 2533$ & Bhind & Gohad & Dhimka \\
\hline 27 & Kubri Mohar & K:1242I & Raipur & Simga & Kesada \\
\hline 28 & Kubri Moharaji & K:1317 & Raipur & Devbhog & Amlipadar \\
\hline 29 & Munibhog & M:1III & Raipur & Bilaigarh & Purgaon \\
\hline 30 & Ramjira & R:440 & Bilaspur & Champa & Madanpur \\
\hline 31 & Rajim-12 & R:169111 & Raipur & Fingeshwar & Raj im \\
\hline 32 & Ramkali & R:273III & Raipur & Tilda & Mohra \\
\hline 33 & Rajabhog & $\mathrm{R}: 399$ & Raigarh & Duldula & Bagvvudri \\
\hline 34 & Sonth & S:715 & Shahadol & Sohagpur & Jodhpur \\
\hline 35 & Safri-11 & S:342II & Durg & Dhamdha & Pendari \\
\hline 36 & Wasmati & $\mathrm{W}: 48$ & Sidhi & Majholi & Khadora \\
\hline
\end{tabular}


Table 2. Mean performances and estimates of genetic components of grain quality traits in aromatic rice.

\begin{tabular}{|c|c|c|c|c|c|c|c|c|c|c|c|c|}
\hline $\begin{array}{l}\text { S.L. } \\
\text { No. }\end{array}$ & Genotypes & $\begin{array}{c}\text { Seed yield } \\
(\mathrm{t} / \mathrm{ha})\end{array}$ & $\begin{array}{l}\text { Hundred } \\
\text { seed wt } \\
\text { (g) }\end{array}$ & $\begin{array}{l}\text { Kernel } \\
\text { length } \\
(\mathrm{mm})\end{array}$ & $\begin{array}{l}\text { Kernel } \\
\text { length: } \\
\text { breadth } \\
\text { ratio }\end{array}$ & $\begin{array}{c}\text { Kernel } \\
\text { length } \\
\text { after } \\
\text { cooking } \\
(\mathrm{mm})\end{array}$ & $\begin{array}{l}\text { Length: } \\
\text { breadth } \\
\text { ratio of } \\
\text { cooked } \\
\text { rice }\end{array}$ & $\begin{array}{l}\text { Milling } \\
(\%)\end{array}$ & \begin{tabular}{|c|} 
Head rice \\
recovery \\
$(\%)$
\end{tabular} & $\begin{array}{c}\text { Elongation } \\
\text { ratio }\end{array}$ & $\begin{array}{c}\text { Elongation } \\
\text { index }\end{array}$ & $\begin{array}{l}\text { Alkali } \\
\text { spreading } \\
\text { value }\end{array}$ \\
\hline 1. & Bikoni & 2.19 & 1.36 & 4.52 & 2.08 & 7.82 & 2.73 & 71.86 & 68.77 & 1.73 & 1.31 & 3.87 \\
\hline 2. & Bantaphool & 1.53 & 1.32 & 4.15 & 1.82 & 7.32 & 1.95 & 70.79 & 55.55 & 1.76 & 1.07 & 3.32 \\
\hline 3. & Bantaphool & 1.92 & 1.32 & 4.40 & 2.11 & 7.52 & 2.33 & 68.80 & 54.59 & 1.76 & 1.10 & 3.13 \\
\hline 4. & Bagmuchha & 2.79 & 1.91 & 5.78 & 2.64 & 8.55 & 2.83 & 65.65 & 61.64 & 1.47 & 1.06 & 3.83 \\
\hline 5. & Banspatn & 2.04 & 1.73 & 5.63 & 3.10 & 7.72 & 2.95 & 73.27 & 52.21 & 1.36 & 0.95 & 3.55 \\
\hline 6. & Barang & 1.89 & 1.24 & 4.07 & 1.91 & 7.32 & 2.26 & 70.94 & 60.49 & 1.80 & 1.71 & 3.50 \\
\hline 7. & Badshahbhog & 2.07 & 1.21 & 5.90 & 2.76 & 8.02 & 2.53 & 64.77 & 58.58 & 1.35 & 0.91 & 3.47 \\
\hline 8. & Bhantaphool & 1.86 & 1.37 & 4.52 & 2.15 & 6.50 & 2.47 & 63.68 & 52.91 & 1.43 & 1.15 & 3.61 \\
\hline 9. & Chhatri & 2.13 & 1.90 & 5.62 & 2.43 & 8.80 & 2.74 & 64.41 & 51.63 & 1.56 & 1.12 & 3.18 \\
\hline 10. & Chinikapoor & 1.86 & 1.43 & 4.25 & 2.05 & 6.73 & 2.23 & 67.93 & 59.82 & 1.58 & 1.08 & 3.17 \\
\hline 11. & Chirainikhi & 2.13 & 1.26 & 4.27 & 1.72 & 6.38 & 2.17 & 70.49 & 62.07 & 1.49 & 1.26 & 3.05 \\
\hline 12. & Dudgi & 1.98 & 1.53 & 4.42 & 1.93 & 6.93 & 2.38 & 70.41 & 61.53 & 1.56 & 1.23 & 3.15 \\
\hline 13. & Dudaga & 2.46 & 1.68 & 5.42 & 2.64 & 7.58 & 2.60 & 64.92 & 67.35 & 1.39 & 0.98 & 3.07 \\
\hline 14. & Dumarphool & 2.16 & 1.20 & 3.97 & 1.87 & 6.22 & 2.13 & 60.90 & 51.93 & 1.56 & 1.14 & 3.32 \\
\hline 15. & Dumarphool & 2.73 & 2.68 & 5.61 & 2.76 & 7.42 & 2.72 & 68.28 & 57.98 & 1.32 & 0.98 & 3.19 \\
\hline 16. & Ganga Balu & 1.68 & 1.11 & 4.42 & 2.12 & 7.72 & 2.86 & 74.84 & 50.22 & 1.74 & 1.34 & 4.31 \\
\hline 17. & Ganga Barud & 3.12 & 1.23 & 4.02 & 1.80 & 6.18 & 1.92 & 68.75 & 61.15 & 1.53 & 1.06 & 3.33 \\
\hline 18. & Ganga Prasad & 2.46 & 1.28 & 4.31 & 1.97 & 6.42 & 2.12 & 73.04 & 43.12 & 1.49 & 1.07 & 4.16 \\
\hline 19. & Garrakat & 2.34 & 1.69 & 5.57 & 2.76 & 7.82 & 2.67 & 67.82 & 51.62 & 1.40 & 0.96 & 3.82 \\
\hline 20. & Jhiili Safri & 1.89 & 1.66 & 5.54 & 2.76 & 8.02 & 2.09 & 69.79 & 61.70 & 1.44 & 0.75 & 4.17 \\
\hline 21. & Jhulari & 2.31 & 1.72 & 5.32 & 2.78 & 8.04 & 2.95 & 67.63 & 57.34 & 1.50 & 1.05 & 4.52 \\
\hline
\end{tabular}


Table 2. Cont'd.

\begin{tabular}{|c|c|c|c|c|c|c|c|c|c|c|c|c|}
\hline $\begin{array}{l}\text { S.L. } \\
\text { No. }\end{array}$ & Genotypes & $\begin{array}{c}\text { Seed yield } \\
(\mathrm{t} / \mathrm{ha})\end{array}$ & $\begin{array}{c}100 \text {-seed } \\
\text { wt (g) }\end{array}$ & $\begin{array}{l}\text { Kernel } \\
\text { length } \\
(\mathrm{mm})\end{array}$ & $\begin{array}{l}\text { Kernel } \\
\text { length: } \\
\text { breadth } \\
\text { ratio }\end{array}$ & $\begin{array}{c}\text { Kernel } \\
\text { length } \\
\text { after } \\
\text { cooking } \\
(\mathrm{mm}) \\
\end{array}$ & $\begin{array}{l}\text { Length: } \\
\text { breadth } \\
\text { ratio of } \\
\text { cooked } \\
\text { rice } \\
\end{array}$ & $\underset{(\%)}{\text { Milling }}$ & $\begin{array}{l}\text { Head rice } \\
\text { recovery } \\
\text { (\%) }\end{array}$ & $\begin{array}{l}\text { Elongation } \\
\text { ratio }\end{array}$ & $\begin{array}{c}\text { Elongation } \\
\text { index }\end{array}$ & $\begin{array}{c}\text { Alkali } \\
\text { spreading } \\
\text { value }\end{array}$ \\
\hline \multicolumn{2}{|c|}{ 22. Jira } & 1.89 & 0.99 & 4.23 & 1.95 & 6.32 & 2.17 & 71.58 & 59.85 & 1.49 & 1.11 & 3.37 \\
\hline \multicolumn{2}{|c|}{$\overline{23 .}$ Jiradhan } & 2.04 & 1.22 & 4.32 & 1.05 & 6.02 & 2.06 & 67.71 & 51.56 & 1.39 & 1.00 & 3.52 \\
\hline \multicolumn{2}{|c|}{ 24. Kalajira } & 1.98 & 1.48 & 3.82 & 1.98 & 5.90 & 2.16 & 75.46 & 68.81 & 1.54 & 1.09 & 3.52 \\
\hline \multicolumn{2}{|c|}{ 25. Krishnabho } & 2.82 & 0.85 & 3.92 & 1.94 & 4.92 & 1.57 & 61.24 & 57.20 & 1.25 & 0.81 & 3.31 \\
\hline \multicolumn{2}{|c|}{ 26. Kalimuchh } & 1.83 & 1.69 & 5.76 & 2.86 & 7.51 & 2.66 & 66.71 & 53.00 & 1.30 & 0.93 & 3.62 \\
\hline \multicolumn{2}{|c|}{ 27. Kubri Moha } & 1.86 & 1.78 & 5.37 & 2.64 & 8.42 & 2.99 & 71.00 & 50.68 & 1.56 & 1.13 & 3.19 \\
\hline \multicolumn{2}{|c|}{ 28. Kubri Moharaji } & 1.92 & 1.63 & 5.42 & 2.82 & 8.02 & 2.81 & 68.71 & 53.661 & 1.47 & 0.99 & 3.31 \\
\hline \multicolumn{2}{|c|}{ 29. Munibhog } & 1.98 & 1.70 & 5.72 & 2.81 & 7.93 & 2.45 & 69.51 & 62.15 & 1.38 & 0.87 & 3.49 \\
\hline \multicolumn{2}{|c|}{ 30. Ramjira } & 2.19 & 0.94 & 4.52 & 1.94 & 6.37 & 2.26 & 71.87 & 54.98 & 1.40 & 1.15 & 3.11 \\
\hline \multicolumn{2}{|c|}{ 31. Rajim-12 } & 3.18 & 1.70 & 5.91 & 2.79 & 8.62 & 2.76 & 62.15 & 54.86 & 1.45 & 0.98 & 4.83 \\
\hline \multicolumn{2}{|c|}{ 32. Ramkali } & 2.31 & 1.49 & 5.51 & 2.72 & 8.02 & 2.84 & 67.25 & 51.45 & 1.45 & 1.04 & 3.64 \\
\hline \multicolumn{2}{|c|}{ 33. Raj abhog } & 3.96 & 1.70 & 5.22 & 2.58 & 8.41 & 3.08 & 66.28 & 53.62 & 1.61 & 1.40 & 3.33 \\
\hline \multicolumn{2}{|c|}{ 34. Sonth } & 2.43 & 1.90 & 5.83 & 2.40 & 7.71 & 2.13 & 65.07 & 56.78 & 1.32 & 0.88 & 4.97 \\
\hline \multicolumn{2}{|c|}{ 35. Safri-11 } & 2.16 & 1.47 & 5.42 & 2.55 & 7.81 & 2.50 & 65.56 & 50.72 & 1.44 & 0.98 & 3.00 \\
\hline \multicolumn{2}{|c|}{ 36. Wasmati } & 1.77 & 1.23 & 4.82 & 2.72 & 6.55 & 2.50 & 72.43 & 59.25 & 1.36 & 0.91 & 3.52 \\
\hline \multicolumn{2}{|c|}{ Mean } & 2.21 & 1.48 & 4.93 & 2.33 & 7.32 & 2.46 & 68.37 & 56.68 & 1.48 & 1.07 & 3.56 \\
\hline \multirow[t]{2}{*}{ Rang } & Min. & 1.53 & 0.85 & 3.82 & 1.05 & 5.90 & 1.57 & 60.90 & 50.22 & 1.25 & 0.75 & 3.00 \\
\hline & Max. & 3.96 & 2.68 & 5.91 & 3.10 & 8.80 & 3.08 & 75.46 & 68.81 & 1.80 & 1.40 & 4.97 \\
\hline \multicolumn{2}{|c|}{$\overline{\mathrm{GCV}}$} & 23.98 & 26.93 & 13.70 & 18.16 & 12.66 & 14.06 & 5.13 & 11.30 & 8.59 & 12.72 & 12.75 \\
\hline \multicolumn{2}{|c|}{ PCV } & 24.44 & 27.71 & 13.75 & 18.27 & 12.67 & 14.54 & 5.22 & 11.35 & 8.70 & 14.34 & 12.95 \\
\hline \multicolumn{2}{|l|}{$h^{2}$} & 0.963 & 0.944 & 0.993 & 0.988 & 0.999 & 0.934 & 0.985 & 0.993 & 0.975 & 0.786 & 0.970 \\
\hline \multicolumn{2}{|c|}{$\mathrm{GA}$ as $\%$ of mean } & 48.46 & 53.84 & 28.14 & 37.44 & 26.07 & 27.93 & 15.78 & 25.33 & 17.56 & 23.58 & 25.91 \\
\hline \multicolumn{2}{|c|}{ CV (\%) } & 4.71 & 6.75 & 1.11 & 1.91 & 0.43 & 3.63 & 0.93 & 1.03 & 1.35 & 5.91 & 2.17 \\
\hline \multicolumn{2}{|c|}{ CD at $5 \%$} & 0.828 & 0.162 & 0.456 & 0.072 & 0.281 & 0.145 & 2.18 & 2.08 & 0.102 & 0.125 & 0.145 \\
\hline
\end{tabular}


In the present study, high broad sense heritability was observed for all the traits. High heritability coupled with high genetic advance was recorded for 100seed weight followed by seed yield per plant, kernel length: breadth ratio, and kernel length, suggesting preponderance of additive gene action in the expression of these characters. Therefore, selection may be effective for the improvement of those characters.

The highest seed yield per plant was recorded in Rajabhog (3.96 t/ha) followed by Rajim-12 (3.18 t/ha) and Ganga Barud (3.12t/ha). The 100-seed weight ranged from 2.68 to $0.85 \mathrm{~g}$. The maximum 100-seed weight was recorded in Dumarphool (2.68g) followed by that of Bagmuchha (1.91g) and Sonth (1.90 g) which can be used for developing varieties with bold seeds. Seed size and shape are the important quality characters in determining market value of rice. Extra long to medium slender are much more preferred by the growers, traders and consumers. Besides this, the physical appearance of rice as an important factor determines its acceptability. Genotypes showed low variation for kernel length with the range from 5.91 to $3.82 \mathrm{~mm}$. Chauhan et al. (1991) also reported low variability for kernel length. Kernel length of Rajim-12 (5.91 mm) was maximum followed by Badshahbhog $(5.90 \mathrm{~mm})$, Sonth $(5.83 \mathrm{~mm})$, Bagmuchha $(5.78 \mathrm{~mm})$, and Kalimuchh $(5.76 \mathrm{~mm})$. Whereas, kernel L:B ratio was maximum for Banspatri (3.10) followed by that in Kalimuchh (2.86), Kubri Moharaji (2.82), Munibhog (2.81), and Rajim-12 (2.79). The genotypes with high kernel length and L:B ratio may be utilized as donors for breeding long grain varieties viz., Rajim-12, Kalimuchh, and Munibhog. Shahidullah et al. (2009) also reported enormous variation in kernel length and L/B ratio. Similarily, kernel length after cooking and L:B of cooked rice are also important cooking quality characters and its higher values are more desirable. Genotypes in the present study showed moderate variation for the kernel length after cooking with the range from 8.80 to $5.90 \mathrm{~mm}$ and high for L:B ratio of cooked rice from 3.08 to 1.57. The maximum kernel length after cooking was registered by Chhatri followed by that in Rajim-12, Baghmuchha, and Kubrimohar, whereas maximum L: B ratio of cooked rice was shown by Rajabhog followed by that of Kubrimohar, Banspatri, and Jhulari. Considering both of these traits, genotypes Rajabhog, Jhulari, and Baghmuchha may be utilized as donors in quality rice breeding programme.

The milling \%, head rice recovery \%, and 100-seed weight being the important quality traits increase the market value from commercial point of view. The range of milling recovery was between 75.46 to 60.90 percent. The moderate milling \% was observed in the genotypes under study indicating little scope for improvement in these traits through selection. The moderate variability for milling recovery was also observed by Chauhan et al. (1991). The highest milling $\%$ was observed in Kalajira followed by that in Ganga Balu, Banspatri, and Ganga Prasad. 
The HRR ranged from 50.22 to $68.81 \%$. The higher head rice recovery (HRR $\%$ ) was recorded in Kalajira followed by Bikoni, Dudaga, Chirainikhi, and Jhilli Safri. The genotypes Kalajira and Bikoni can be used as donors for breeding varieties of quality rice from the commercial point of view.

The elongation ratio and elongation index are the important cooking quality traits of rice. The higher values of these traits are desirable and much preferred by the consumers. Moderate variability was observed for elongation ratio and elongation index with range between 1.80 to 1.25 and 1.40 to 0.75 , respectively. Maximum kernel elongation ratio was observed in Barang followed by that in Bantaphool, Ganga-Bain, and Bikoni, whereas highest elongation index was registered by Barang, Rajabhog, Ganga Balu, Bikoni, and Chirainikhi confirming the results of Shahidullah et al. (2009) and Rathi etal. (2010).

Alkali spreading value is also one of the important cooking quality traits and its intermediate scores (4-5) indicate intermediate amylose content. It ranged from 4.97 to 3.00 confirming the results of Rathi et al. (2010). The people of India prefer varieties with intermediate amylose content. The genotypes Sonth, Rajim12, Jhulari, Ganga Balu, Jhilli Safri, and Bikoni had intermediate alkali spreading values which can be utilized as donors in quality rice breeding programme.

The present study evaluated the yield performance, physico-chemical characters, and cooking quality traits of aromatic rice genotypes representing different eco-graphical conditions of Chhattisgarh and Madhya Pradesh. This will be helpful in assessing the varietal characters for selecting parents viz., Rajim-12, Kalimuchh, Munibhog as fine grain genotypes for moderate kernel length and L:B ratio; Rajabhog, Jhulari, Baghmuchha for kernel length after cooking and L:B ratio ; Bikoni for head rice recovery \%; Barang, Bantaphool, Gangabalu, Bikoni for elongation ratio; Barang Rajabhog, Gangabalu, Bikoni, Chirainikhi for elongation index; Sonth, Rajim-12, Jhulari, Gangabalu, Safri, Milli and Bikoni for intermediate alkali value towards improvement of respective traits in quality rice breeding programme.

\section{References}

Burton G.W. 1952. Quantitative inheritance in grasses. In proceedings of $6^{\text {th }}$ International Grassland Congress Ames, Iowa, USA Pp. 227-283.

Chauhan J. S., V. S. Chauhan,and S. G. Lodh. 1991. Abstr. Golden Jubilee symposium on Genetic Research and Education: Current Trends and Next Fifty Years. 1: 16.

Little R. R., G. S. Hildser and E. H. Dawson. 1958. Differential effect of dilute alkali on 25 varieties of milled white rice. Cereal Chem. 35: 111-126. 
Johnson H. W., H. F. Robinson and R. E. Comstock. 1955. Estimates of genetic and environment variability in soyabean. Agron. J. 47: 314-318.

Pandey Praveen and P. John Anurag. 2010. Estimation of genetic parameters in indigenous rice. Advances in Agriculture and Botanics 2(1): 79-83.

Shahidullah S. M., M. M. Hanafi, M. Razi Ashrafuzzaman Ismail and A. Khair. 2009. Genetic diversity in grain quality and nutrition of aromatic rices. African Journal of Biotechnology 8(7): 1238-1246.

Rathi S., R. N. S. Yadav and R. N. Sarma. 2010. Variability in grain quality characters of upland rice of Assam, India. Rice Science 17(4): 330-333. 